\title{
THE EFFECT OF THE QUALITY OF FINANCIAL REPORTING ON THE DEVELOPMENT OF THE LEVEL OF QUALITY OF PROFITS DECLARED IN THE FINANCIAL REPORTS OF BANKS LISTED ON THE PALESTINE EXCHANGE-AN EMPIRICAL STUDY
}

\author{
Issam M. A. AL Tawee $\mathbf{L}^{1 *}$
}

${ }^{* 1}$ Asst. Prof. of Accounting \& Auditing, Faculty of Management \& Finance in Al-Aqsa University, Gaza, Palestine, Email: imat1976@hotmail.com

*Corresponding Author: -

Email:imat1976@hotmail.com

\begin{abstract}
: -
The study aimed to demonstrate the impact of the quality of financial reporting on developing the level of the quality of profits announced in the financial reports of banks listed on the Palestine Stock Exchange. The study relied on a sample of (6) banks listed on the Palestine Stock Exchange during the period (2014-2017). The study developed the level of profits quality as a dependent variable, while the independent variables included accuracy, appropriateness and appropriate timing for financial reporting, and the results of the study showed that there is a positive impact at the level of significance $(\alpha \leq 0.05)$ of accuracy on the level of profit quality declared for banks listed on the Palestine Stock Exchange. There is an adverse effect at the level of significance $(\alpha \leq 0.05)$ of the suitability and the appropriate timing at the level of the quality of profits declared for the banks listed on the Palestine Stock Exchange. By providing information to its users in a timely manner, otherwise, this information will lose its value, and the need for continuous development of financial reporting reports in light of the emerging and changing needs of users of financial reports or other stakeholders.
\end{abstract}

Keywords: - financial reporting, quality of profits declared, banks, Palestine Exchange.

\section{(a) $(\$)$}




\section{INTRODUCTION:}

Accounting information is one of the most important sources of information for the beneficiary parties - including investors and the financial market in particular - and therefore improving the quality of accounting information is a major requirement for these recipient parties, and since the financial reporting system is one of the most prominent accounting trends towards interest in producing, interpreting, and communicating accounting information to The beneficiary parties, free from fundamental distortions and giving them a true and fair picture of the financial position and the result of the activity of the company, and consequently, its high predictive ability to assess the current and future status of the company, so setting and adhering to quality standards for accounting information is an essential requirement and requirement for each of the recipient parties and accountants themselves, as they have It is of great importance in the field of making various decisions for the beneficiary parties, a requirement for what accounting provides and a basis for its survival.

Financial reporting is the most important output of the accounting process because it relates to other parties outside the company's management or the so-called "stakeholders", whose decisions depend on what is disclosed of data and information about the financial position and other activities that pertain to the company, and as a result this information must have the relevance and reliability that states It has international accounting standards and profession standards issued by the relevant authorities.

Profits - regardless of their quality - are considered an important input in the process of making financial and investment decisions, and profits are used in many predictive and evaluation studies of the company's current and future performance, and since the quality of the profits is due to the ability of the profits disclosed to express the real profits of the company and its benefit In predicting future profits, the quality of profits is an important aspect in assessing the financial position of companies by many parties such as investors, prospective and creditors, and the profit gap is used in the company as an indication of the dividends taken into account when making investment decisions (Faouri, 2011).

(Demerjian, 2013) has stated that the importance of quality profits stems from the fact that the investor depends in his decisions on the significance, timing and transparency of the financial statements, so if the company does not disclose significant financial information to the investor regarding what it was, what it is now and what it will become In the future, this will result in investor misinformation which leads to a lack of confidence in financial information in the capital markets.

As the financial statements are prepared for the purpose of providing adequate information about the activities of the economic unit, the information contained therein must be of high quality because it will positively affect the decisions of stakeholders such as owners, investors, and creditors, and that these decisions enhance the efficiency of the financial market, which is confirmed by the International Accounting Standards Board. (Beast, et.al., 2009), and one of the main major problems is how to measure this quality, which this study will address in explaining the possibility of measuring the impact of the quality of financial reporting on the development of the level of quality of accounting profits announced in the financial reports.

\section{Study Problem:}

The concept of financial reporting refers to the activities that companies engage in with the aim of presenting and communicating information to decision makers, especially investors, and for this financial reporting must enjoy a high level of quality that stems from the group adhering to quality standards, since quality has an important role in the behavior of decision makers. Whenever there is quality in financial reporting, the degree of dependence on reports prepared in different fields increases, including the development of the level of quality of profits announced in financial reports, so attention was focused on studying and analyzing the role of quality of financial reporting in developing the level of quality of profits announced in banks 'financial reports Listed on the Palestine Exchange, based on the above, the problem of the current study can be represented by raising the following main question:

Does the quality of financial reporting affect the development of the level of quality of profits announced in the financial reports of banks listed on the Palestine Exchange?

\section{From it the following questions emerge:}

First: Does the accuracy of financial reporting have a positive relationship and effect in improving the level of quality of profits announced in the financial reports of banks listed on the Palestine Exchange?

Second: Is the appropriateness of financial reporting a relationship and a positive impact in improving the quality of profits announced in the financial reports of banks listed on the Palestine Stock Exchange?

Third: Is the appropriate timing of financial reporting a relationship and a positive impact in improving the level of quality of profits announced in the financial reports of banks listed on the Palestine Stock Exchange?

\section{Objectives of the study:}

The current study aims mainly to indicate the impact of the quality of financial reporting on the development of the level of quality of profits announced in the financial reports of banks listed on the Palestine Stock Exchange, through the following objectives:

1. Determine the relationship of financial reporting accuracy in developing the level of quality of profits announced in the financial reports of banks listed on the Palestine Exchange.

2. A statement of the contribution and appropriateness of financial reporting in developing the level of quality of 
profits announced in the financial reports of the banks listed on the Palestine Stock Exchange.

3. Revealed the role of appropriate timing for financial reporting in developing the level of quality of profits announced in the financial reports of banks listed on the Palestine Stock Exchange.

\section{Importance of the study:}

The importance of the current study stems from its contribution to achieving the following:

1- Activating the role of financial reporting and activating the importance of the quality of this system in improving the quality of profits.

2- Proof of the impact of raising the quality of financial reporting on the impact on improving the quality of profits positively, which are the most important factors for the success and survival of companies.

3- The Palestinian library in particular and the Arab library in general need such research as a result of its rarity.

\section{Study hypotheses:}

The study and analysis of study variables and their relationship are based on a major hypothesis that:

The quality of financial reporting has a positive relationship and impact in developing the level of profit quality advertised in the financial reports of banks listed on the Palestine Stock Exchange.

\section{Three sub-hypotheses derive from this hypothesis:}

The first hypothesis: The accuracy of financial reporting has a positive relationship and effect in developing the level of quality of profits announced in the financial reports of banks listed on the Palestine Stock Exchange.

The second hypothesis: The appropriateness of financial reporting has a relationship and positive impact in developing the level of quality of profits announced in the financial reports of banks listed on the Palestine Exchange.

The third hypothesis: The appropriate timing of financial reporting has a relationship and positive impact in developing the level of quality of profits announced in the financial reports of banks listed on the Palestine Stock Exchange.

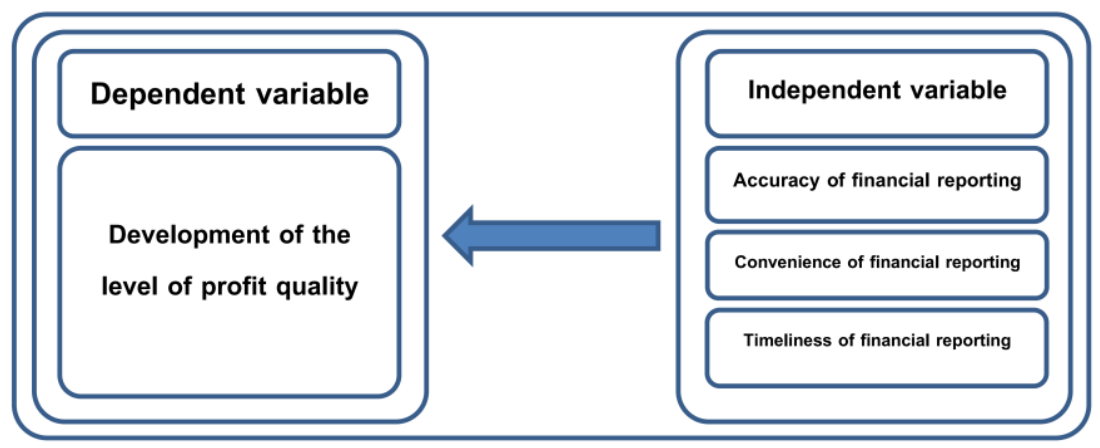

Figure 1: Study model

\section{Procedural definitions: Quality of financial reporting}

The quality of financial reports means that they are free from material misrepresentations and give them a true and fair picture of the company's performance and financial position, and thus their high predictive ability to assess the current and future status of the company.

\section{Accounting profit quality}

It means the continuity of profit flow and forecasting future profits, as well as forecasting the future performance of the company.

\section{Theoretical framework and previous studies financial reporting quality}

FASB sees it as a reflection of a set of qualitative characteristics of accounting information, based on that reliability, and its relationship to this topic as a key consideration in addition to another set of quality characteristics such as relevance, accuracy, impartiality, comparability, feedback and timeliness, and the issue of quality of financial reporting remains a natural result For Business Quality (Nashwe, 2003).

\section{Financial reporting quality characteristics:}

Quality means that the information provided is available to everyone and is useful for making decisions, and that its quality depends on a number of characteristics that cannot be dispensed with, and that its absence means the lack of benefit from it in decision-making and includes (Aljjawi and Al-Masoudi, 2014):

a. Appropriateness: It is the ability of accounting information to influence the decisions of its users, negatively or positively.

b. Sincere representation: that financial reports are numbers and values that reflect an image of economic unity, and in order to reflect the reality of that image you must represent it truthfully and fairly and not only highlight the appropriate aspects.

c. Comparability: The information should be comparable between the options presented to stakeholders to choose the best one. 
d. Verification: The information provided in the financial reports must lead to the realization of the option taken accordingly.

e. Temporal: to provide information in a timely manner to make decisions that will benefit from them, and as a result, increase the quality of the decisions taken on their basis.

f. Understanding: The smooth display of information in financial reports makes it understandable regardless of the level of users of that information.

\section{Quality of accounting profits:}

Both auditors and auditors believe that profits are of high quality if disclosed in accordance with generally accepted accounting principles, but that creditors consider them so whenever they have greater ability to convert into cash flows, and profits are seen as being High quality if you express the true performance of managers without any influence from external factors on their control (Dechow \& Schrand, 2004).

\section{The factors affecting the quality of profits:}

The most important of these factors that affect the quality of profits can be identified as follows: (Obaid and Akbar, 2016)

1. Quality accounting standards that prevent management from practicing profit management.

2. The difference in accounting standards used in preparing financial reports, between local and international standards, leads to exploiting the differences between them.

3. Installing shareholders, it was found that profit management practices in companies that have the highest percentage of members of the board of directors as they have a significant impact in making decisions in the policy of economic unity.

4. The shareholders' control in some countries with socialist systems, where the state controls a percentage of the companies 'shares, and the shareholders' control rate decreases by less than half, the quality of the profits decreases in such companies.

5. The impact of the audit committee on the quality of profits, as the increased interest in audit committees in the recent period leads to improving the quality of profits.

6. The principles and foundations of corporate governance contributed to improving the quality of profits (Machaga \& Teitle, 2007).

7. The quality of internal control also plays a role in improving the quality of profits (Altmauro \& Beatty, 2006).

\section{Previous Studies:}

Dechow \& Dechiv (2002) study entitled "The Quality of Accruals and Earning; The Role of Accruals Estimation Errors" aimed to measure the quality of profits (the quality of receivables was used as an indicator of the quality of profits) by analyzing the relationship between receivables from working capital items and flows Cash from operating activities for the previous, current and future periods based on the assumption that the dues from capital items are temporary settlements that transfer cash flows over different time periods, and the study provided the following experimental model: (which became known as D. D Measure), and the study attempted Exploring the relationship between the quality of receivables and the characteristics of the company, and reached to identify the characteristics that lead to a decrease in the quality of profits, which are the length of the operations cycle, the small size of the company, the variation in sales from year to year, income variation from year to year (including its detailed components from dues and cash flows) and an estimate Negative income (losses), as well as a direct relationship between the quality of receivables and the stability or continuity of income.

Penman \& Zhang (2002) conducted a study titled "Accounting Conservatism, the Quality of Earnings and Stock Returns" whose purpose was to measure the effect of an accounting reservation on the quality of accounting earnings and stock returns, and the study concluded that the effect of a single accounting reservation on the quality of income leads to Weak results, and that it must be used in light of the growth in the size of the company's investments, and that if the company is characterized by high investment growth rates, the accounting reservation leads to undesirable results on income and returns because this allows the company to create secret reserves that can be used to manage profits, especially When this growth in investments is temporary.

The study of Beuselinck \& Manigart (2007) titled "Financial Reporting Quality in Private Equity Backed Companies: the Impact of Ownership Concentration" tested the quality of information produced in companies backed by shares applying to a sample of (270) Belgian companies The study found that private equity investors obtain a large share in the company (meaning more precisely managing high profits, and the timing of recognizing losses) leads to poor quality of financial reporting, and financial reporting is of high quality when their share is small and thus enables external stakeholders to take Their decisions mainly depend on the quality of financial reporting in the accounts of those companies, and stakeholders should not take the quality of financial reporting performance on its face, despite the fact that the quality of the accounting numbers of companies supported by private shares is generally better than similar companies that are not supported by equity investors Own.

The study of Machuga \& Teitel (2007) entitled "The Effects of the Mexican Corporate Governance Code an Quality Earnings and its Components" aimed to test the impact of the quality of profits in the corporate governance law applied in Mexico in 2000, aimed at encouraging management to issue financial reports enjoying greater degree of Accuracy, transparency and disclosure, and the quality of profits was measured through several measures: the ratio of the absolute value of the change in income divided by the absolute value of the change in cash flows, and this ratio shows the degree 
of occurrence of income preparation, the timing of recognition of losses, unfair dues, and the results of the study reached That the quality of profits increased after the application of the Corporate Governance Law.

As for the study of Al-Shujairy and Al-Mazury (2008) entitled "The impact of the quality of financial reporting on the value of the enterprise", they presented the problem of accounting information that is a source of investor decisions and testing it by linking the relationship between the impact of financial reporting and the value of the enterprise and its role in stimulating financial markets, assuming that there is a positive relationship between them, The study found that there is an effect of financial reporting on the market value and recommending the necessity to pay careful and appropriate attention and disclosure of financial statements in a way that increases the expected benefits from them by dealers in the Iraq Stock Exchange. The study was aimed at Wu De. Jun, (2009) entitled "What are affecting earnings quality", determining the factors that affect the quality of accounting profits. To achieve this goal, the researcher studied the theory from five approaches: accounting standards, company characteristics, capital composition, characteristics of internal audit committees, and the characteristics of a board of directors, the company and the characteristics of the external auditing firms. The study concluded the effect of each of the previous entries on the quality of accounting profits.

Saleh's study (2010) entitled "The role of investors in providing the quality of financial reporting and its implications for investment decision-making - a field study on the Iraq Stock Exchange" aimed to identify the concept of quality of financial reporting and clarify the role of investors in assessing its quality and its reflection on the investment decisions they make The Administration drew the attention of the Iraq Stock Exchange and its supervisory authority, as well as other relevant bodies, to the need to carry out continuous development of financial reporting reports in the light of the emerging and changing needs of investors and other stakeholders. Among the most important findings of the study is that the needs and behavior of investors have an impact on the quality of reporting reporting This is because the lack of accounting knowledge and the ignorance of investors in accounting matters and the inability to properly read the financial statements of listed companies and the information attached to them make many investors victims Losses in the capital markets.

Hamdan (2012) also presented a study entitled "The role of the audit committees in the continuity of profits as evidence of their occurrence" as this study aimed to verify the quality of the profits of the industrial public shareholding company listed on the Amman Stock Exchange, in addition to testing factors that affect the level of profit quality in These companies, namely: the accounting reservation, the size of the company, debt contracts, return on investment, institutional control, quality of audit, and audit committees. The study reached important results that indicate the high quality of the profits of Jordanian industrial public shareholding companies, and the results also indicated an impact. The size of the company, debt contracts and the quality of the audit of the level of profit quality.

Reda (2012) also presented a study titled "The effect of auditing quality on the quality of profits and their repercussions on the cash dividends in Egyptian industrial joint-stock companies" aimed at revealing the relationship between the quality of the external audit and the quality of profits and then determining the effect of quality of profits on cash dividends in the Arab Republic of Egypt, The study concluded that there is a positive impact of both the value of the audit fees and the size of the audit office and the link with the international offices of auditing and professional qualification on the quality of profits represented by the reduction of the total dues, and that there is a negative impact of the customer retention period on the quality of profits, and the study also found a positive impact of quality Profits on the rate of cash dividends in Egyptian industrial joint-stock companies.

In a study of Melji (2013) entitled "The impact of internal audit activities on the management and quality of profits as an entry point to improve the relevance and reliability of financial statements", the study aimed to discover the extent to which Saudi commercial banking management practices in the stock market practice profit management and the quality of profits in them on the other hand, And examining the impact of the quality determinants of audit activities: the academic qualification, the professional qualification, experience, the size of the audit department, organizational independence, the internal audit work guide, and evaluating the quality of its activities in reducing the practice of profit management and improving its quality, as well as examining the impact of the quality of internal audit activities on achieving reliability suitability On the financial statements of commercial banks on the other hand, and one of the most important results of the study is the identification of useful information for parties interested in the internal audit regarding indicators to infer their quality, and their impact on the management and quality of the profits of commercial banks to achieve the relevance and reliability of the lists in commercial banks.

Demerjian, et.al (2013) study entitled "Managerial Ability and Earning quality" aimed to demonstrate the relationship between administrative capacity and the quality of profits, and it has been found that the quality of profits is directly correlated with administrative capacity, with higher profits and consistency of receivables, as the study demonstrated A management that has a greater ability to reduce its errors in estimating bad debts and achieving quality in determining entitlements, and these results are coordinated with the assumption that managers can influence the quality of judgments and estimates used to form profits.

Ibrahim (2014) study entitled: "The relationship between the quality of profits and the company's exposure to financial risk risks" examined the relationship between the quality of profits and the potential for financial failure of Egyptian joint stock companies registered on the stock exchange, and the study concluded that the company's exposure to financial risk risks depends on both From: the value of the optional entitlements of the company and the continuity of the company's profits in the future as an indicator to measure the quality of profits, the rate of return on investment and the rate of return on shareholders 'equity as indicators for measuring the efficiency of the company's money use, the percentage of leverage as an indicator of the company's debt ratios, the ratio of trading and the rapid liquidity ratio as indicators to measure the company's investment in More liquid assets, the ratio of the capital structure in long-term 
assets as an indicator to measure and achieve a financial balance between the financing structure and the structure of the company's assets, the degree of total leverage as an indicator to measure the size of fixed cash obligations, and finally the ratio of long-term liabilities to total liabilities as an indicator to measure the company's dependence on fewer funding sources Risky.

As the study of Al-Masoudi and Al-Jabouri (2016), entitled "The effect of good financial reporting on enhancing the value of the economic unit," showed that preparing financial statements should reflect the activity of the economic unit, and among the factors that affect that activity are the quality of financial reporting, and the most important obstacles facing Iraqi economic units are The problem of achieving a high level of quality of financial reporting on its economic activities, that investors often resort to financial statements to know the financial position and the financial information it provides and the extent of the impact of the quality of financial reporting on the market value, which is the goal that the research seeks to achieve by assuming that the quality of financial reporting An effect in enhancing the market value of the share of the economic unit, as the quality of financial reporting was measured by relying on mathematical equations that include measuring the quality of financial reporting for economic units - the research sample - and showing the extent of its impact on the market share value, and concluded that the disclosure of financial information has effects in the decision-making process One of the users of the financial statements, and as a result, the effect on the market value of the economic unit.

As for Al-Muaini and Nuri (2017) study titled "The Impact of Financial Reporting Quality on Added Market Value", attention was focused on studying and analyzing the role of financial reporting quality in the added market value, as the research relied on testing its topic on a major hypothesis directed to test the impact between the quality of reporting Financial and market value added, so the research reached a set of conclusions, the most important of which was the presence of a statistically significant effect of the quality of financial reporting on the market value added of companies in the research sample.

Azwail and Bardai (2018) study entitled "The role of applying corporate governance in the quality of profits" aimed to identify the role of institutional governance in the quality of profits from the viewpoint of managers of financial departments in industrial companies operating in Ramallah, and the study reached several results, the most important of which are: Corporate governance works to provide transparency and disclosure of the information necessary for its accounting reports and financial statements in order to protect the interests of depositors and protect the interests of other groups.

\section{The present study was distinguished from other previous studies in the following:}

It is clear from the previous review of previous research and studies related to the subject of the research, that there is a difference between it and this study, which can be summarized in the following:

1. None of the previous researches and studies dealt with to measure the effect of the quality of financial reporting on the development of the level of quality of profits announced in the financial reports of banks listed on the Palestine Stock Exchange, and this is what distinguishes this study from other studies and research.

2 Previous studies dealt with more than one quality of financial reporting, and these studies differ from my current study in that it will take three attributes as measures of the quality of financial reporting, namely accuracy, relevance, and reliability.

3. This study connects between two important variables that were not discussed in any previous study; the first variable is the quality of financial reporting and the second variable, which is to develop the level of quality of profits announced in the financial reports of banks listed on the Palestine Stock Exchange.

4. This study attempts to make good contributions to research and studies that directly study the effect of the quality of accounting profits on developing the level of quality of profits announced in financial reports.

5. Previous studies were conducted on countries with full sovereignty, and they have active financial markets and supreme supervisory bodies, while the current study is being conducted on the State of Palestine, whose financial facilities suffer from a major deficiency in their performance.

\section{Research Methodology:}

Based on the nature of the study and the goals that it seeks to achieve, the researcher used the descriptive analytical approach, which depends on studying the phenomenon as it exists in reality and is interested as an accurate description and expresses it qualitatively and quantitatively, and this approach is not sufficient when collecting information related to the phenomenon in order to investigate its manifestations and its relationships It differs from it to analysis, correlation and interpretation to reach conclusions upon which the proposed concept is based, so that it increases the balance of knowledge on the subject.

\section{The researcher used secondary sources to obtain information:}

Where the researcher went to address the theoretical framework of the research to secondary data sources, which are represented in the relevant Arab and foreign books and references, periodicals, articles and reports, and previous research and studies that dealt with the topic of study, research and reading in various internet sites, and to address the analytical aspects of the subject of the study the researcher resorted to collecting Secondary data through the financial statements published by the companies listed on the Palestine Exchange every year, collect them and take the necessary data from them, as well as annual and interim financial reports. 


\section{Study community:}

The study community consists of all public shareholding companies registered in the Palestine Securities Exchange in the banking sector, and therefore the number of banks listed on the Stock Exchange has reached (7) banks listed on the Palestine Securities Exchange.

As for the study sample, it is a comprehensive sample of all companies that achieve the following conditions:

- They are not companies that were merged with other companies, or were newly listed on the Palestine Securities Exchange.

- The financial statements disclosed according to the standards are not clear and not sufficient to implement the standard.

Thus, the study sample that achieved the previous two conditions and completed its financial data necessary to estimate the study variables is made up of (6) banks listed on the Palestine Securities Exchange, and the Palestine Securities Exchange Company was excluded as shown in Table 1. Table 1 shows the study population and its sample as follows:

Table 1: The study population and sample

\begin{tabular}{|c|c|c|}
\hline Companies in the study & \multicolumn{2}{|c|}{ Palestine Securities Exchange } \\
\cline { 2 - 3 } sample & number & Ratio \\
\hline Recorded & 7 & $\% 100$ \\
\hline Excluded & 1 & $\% 14.3$ \\
\hline The study sample & 6 & $\% 85.7$ \\
\hline
\end{tabular}

\section{Measuring search variables:}

The research employed a set of measures for its variables, and it was based on a set of related studies in line with the data disclosed in the Palestine Stock Exchange database. Essentially, several international models were adopted on the Dechow, Sloan \& Sweeney (1995) model to measure the quality of profits, and the (McNichols model, 2002) to measure the accuracy of financial reporting, and the (Easton and Harris, 1991) model to measure the appropriateness of financial reporting, and (Basu, 1997) to measure the appropriate timing variable, and the following illustrates methods for measuring variables:

First: dependent variable (profit quality)

Dechow, Sloan \& Sweeney (1995) model for measuring total receivables:

TAC $=\Delta$ CA $-\Delta$ CL- $\Delta$ CASH + DE STDEBT - DEP
\begin{tabular}{|l|c|}
\hline Total benefits & TAC \\
\hline Change in current assets & $\Delta$ CA \\
\hline Change in cash & $\Delta$ CASH \\
\hline Change in current liabilities & $\Delta \mathrm{CL}$ \\
\hline Change in short-term debt & $\Delta$ STDEBT \\
\hline Explosions & DEP \\
\hline
\end{tabular}

\section{Or it will be calculated through}

Total receivables $=$ net operating income - cash flow from operating activities Regular accruals $=$ (current activity revenue - short-term credit) / fixed assets Unusual dues = total dues - regular dues

If the value of the unusual dues is positive, then this indicates a high quality of profits. If it is negative, this means a low quality of profits.

Second: The independent variable (quality of financial reporting)

\begin{tabular}{|c|l|}
\hline $\begin{array}{c}\text { First: Accurate financial } \\
\text { reporting } \\
\text { (Model (McNichols, 2002 }\end{array}$ & $\begin{array}{c}\text { Accrualsi,t }=\alpha+\beta 1 * \text { Cash Flowi,t } 1+\beta 2 * \text { Cash Flowi,t }+\beta 3 * \\
\text { Cash Flowi,t }+14 * \Delta \text { Revenuei, } t+\beta 5^{*} \text { PPEi, } t+\Sigma i, t\end{array}$ \\
\hline Accrualsit & The value of the dues of the company in the current period \\
\hline Cash flow & $\begin{array}{c}\text { The company's cash flow is equal to net profit before interest } \\
\text { and taxes minus the dues. }\end{array}$ \\
\hline Cash flowi,t-1 & Company cash flow i, in the previous period \\
\hline Cash flowi, t & Company cash flow i, in the current period \\
\hline Cash flowi,t+1 & Company cash flow i, in the coming period \\
\hline$\Delta$ revenue & Change in revenue \\
\hline PPE & The value of fixed assets \\
\hline
\end{tabular}




\begin{tabular}{|c|c|}
\hline $\begin{array}{l}\text { Second: The appropriateness of financial } \\
\text { reporting } \\
\text { (Model (Easton and Harris, } 1991\end{array}$ & $\begin{array}{c}\text { EPSit } / \text { Pt-1 }=\text { EPSt- } 1 / \text { Pt-1 }+\Delta \text { EPS } / \text { Pt-1 } \\
\ldots \ldots \ldots .1 \\
\text { Ri, } t=\alpha+\beta^{*} \text { EPSit } / \text { Pit- } 1+\Sigma \text { it } \ldots \ldots \ldots . .2\end{array}$ \\
\hline EPSit & $\begin{array}{l}\text { Earning per share for the company in the time } \\
\text { period }\end{array}$ \\
\hline Pt-1 & $\begin{array}{l}\text { The stock price in the market in the previous } \\
\text { period }\end{array}$ \\
\hline EPSt-1 & Earnings per share in the last period \\
\hline$\triangle E P S$ & Change in earnings per share \\
\hline Rit & $\begin{array}{l}\text { Earning per share for the company over the } \\
\text { time period }\end{array}$ \\
\hline
\end{tabular}

\begin{tabular}{|c|c|}
\hline $\begin{array}{c}\text { Third: The appropriate timing } \\
\text { for financial reporting } \\
\text { Model (Basu, 1997) }\end{array}$ & NIit $=\beta 0+\beta 1$ DRit $+\beta 2$ Rit $+\beta 3$ Rit * DRit \\
\hline NIit ( EPS ) & Earning per share for the company in the time period \\
\hline Drit & $\begin{array}{c}\text { The binary variable takes one value if the adjusted market returns } \\
\text { for the company the study sample is negative, and takes a value of } \\
\text { zero if the opposite is. }\end{array}$ \\
\hline Rit & $\begin{array}{c}\text { Realized share return: It takes one value if the returns are } \\
\text { negative, and it takes a value of zero if it is positive, and it is } \\
\text { calculated as follows: }\end{array}$ \\
\hline
\end{tabular}

\section{The statistical method used to obtain the results of the statistical analysis:}

Statistical analysis will go through several important steps to reach the results of hypotheses and research objectives, which are:

1. The values of the variables will be extracted by referring to the specified forms, and conducting descriptive statistics according to the bank and the year.

2. Calculating the estimated (predictive) data for each of the variables through the following equation: $\mathrm{y}^{\wedge}=\mathrm{X}$ (base year) $(1+\mathrm{g}) \mathrm{t}$ Whereas:

$Y$ : the estimated (predictive) value of the variable based on historical data.

$\mathrm{X}$ : the value of the independent variable in the base year, and the base year will be used as the last year in the data to ensure its accuracy and accuracy.

g: average variable rate of growth for the period 2014-2017. t: time period (forecast or forecast period).

3. The values of (15) future years will be predicted from the last available value, and the values will be extracted for all variables, and entered via the spss program, to be ready.

4. Conducting the form validity test for statistical analysis before performing the necessary statistical tests and ensuring that the form is compatible and valid for the analysis.

First: descriptive statistics of the study variables

As we said earlier, the first research procedures were to extract descriptive statistics for independent and dependent research variables based on the bank and the year, and the following tables show the results.

Table 2: The level of accuracy of financial reporting for the banks listed on the Palestine Exchange

\begin{tabular}{|l|c|c|c|c|c|c|c|c|}
\hline The bank & $\mathbf{2 0 1 4}$ & $\mathbf{2 0 1 5}$ & $\mathbf{2 0 1 6}$ & $\mathbf{2 0 1 7}$ & $\begin{array}{l}\text { Highest } \\
\text { value, }\end{array}$ & $\begin{array}{l}\text { lowest } \\
\text { value, }\end{array}$ & Average & Ranking \\
\hline Islamic Arab & 26.51 & 31.46 & 33.11 & 20.48 & 33.11 & 20.48 & $\mathbf{2 7 . 8 9}$ & 5 \\
\hline $\begin{array}{l}\text { Palestinian } \\
\text { Islamic }\end{array}$ & 8.78 & -9.00 & 18.00 & 37.57 & 37.57 & -9.00 & $\mathbf{1 3 . 8 4}$ & 6 \\
\hline $\begin{array}{l}\text { Palestinian } \\
\text { investment }\end{array}$ & 34.33 & -8.68 & 39.55 & 58.88 & 58.88 & -8.68 & $\mathbf{3 1 . 0 2}$ & 4 \\
\hline Palestine & 316.71 & 80.91 & 131.35 & 622.55 & 622.55 & 80.91 & $\mathbf{2 8 7 . 8 8}$ & 1 \\
\hline Al-Quds & 70.74 & 93.36 & -77.61 & 222.34 & 222.34 & -77.61 & $\mathbf{7 7 . 2 1}$ & 2 \\
\hline the National & 35.13 & 46.01 & 64.39 & 88.60 & 88.60 & 35.13 & $\mathbf{5 8 . 5 3}$ & 3 \\
\hline The average & 82.03 & 39.01 & 34.80 & 175.07 & & & $\mathbf{8 2 . 7 3}$ & \\
\hline
\end{tabular}

It is clear from the previous table, the variation levels of accuracy between banks, and the following things were observed according to the previous descriptive statistics:

1. The highest value of bank accuracy was for the Bank of Palestine in 2017.

2. The lowest value of the accuracy between banks was Al-Quds Bank in 2016. 
3. The Bank of Palestine received the highest average accuracy over the years, followed by Al-Quds Bank, then the National Bank, then the Palestinian Investment Bank, and then the Arab Islamic Bank, while the Palestinian Islamic Bank ranked last.

Table 3: the level of suitability of financial reporting for the banks listed on the Palestine Exchange

\begin{tabular}{|c|c|c|c|c|c|c|c|c|}
\hline The bank & $\mathbf{2 0 1 4}$ & $\mathbf{2 0 1 5}$ & $\mathbf{2 0 1 6}$ & $\mathbf{2 0 1 7}$ & $\begin{array}{c}\text { Highest } \\
\text { value, }\end{array}$ & $\begin{array}{c}\text { lowest } \\
\text { value, }\end{array}$ & Average & Ranking \\
\hline Islamic Arab & 1.71 & 1.29 & 1.44 & 1.09 & 1.71 & 1.09 & $\mathbf{1 . 3 8}$ & 2 \\
\hline Palestinian Islamic & 1.27 & 1.54 & 1.39 & 1.10 & 1.54 & 1.10 & $\mathbf{1 . 3 3}$ & 4 \\
\hline $\begin{array}{c}\text { Palestinian } \\
\text { investment }\end{array}$ & 1.67 & 1.00 & 1.00 & 1.60 & 1.67 & 1.00 & $\mathbf{1 . 3 2}$ & 5 \\
\hline Palestine & 1.05 & 1.10 & 1.26 & 1.07 & 1.26 & 1.05 & $\mathbf{1 . 1 2}$ & 6 \\
\hline Al-Quds & 2.00 & 1.50 & 1.36 & 1.36 & 2.00 & 1.36 & $\mathbf{1 . 5 6}$ & 1 \\
\hline the National & 1.58 & 1.01 & 1.22 & 1.51 & 1.58 & 1.01 & $\mathbf{1 . 3 3}$ & 3 \\
\hline The average & 1.55 & 1.24 & 1.28 & 1.29 & & & $\mathbf{1 . 3 4}$ & \\
\hline
\end{tabular}

It is clear from the previous table, the differences in the levels of convenience between banks, and the following matters were observed according to the previous descriptive statistics:

1. The highest value of interbank balance was for Al Quds Bank in 2014.

2. The lowest value for interbank balance was for the Palestinian Investment Bank in 2015 and 2016.

3. Al-Quds Bank received the highest average score during the years, followed by the Arab Islamic Bank, then the National Bank, then the Palestinian Islamic Bank, then the Palestinian Investment Bank, while Bank of Palestine ranked last.

Table 4: The appropriate level of timing for financial reporting to the banks listed on the Palestine Exchange

\begin{tabular}{|c|c|c|c|c|c|c|c|c|}
\hline The bank & $\mathbf{2 0 1 4}$ & $\mathbf{2 0 1 5}$ & $\mathbf{2 0 1 6}$ & $\mathbf{2 0 1 7}$ & $\begin{array}{c}\text { Highest } \\
\text { value }\end{array}$ & $\begin{array}{c}\text { lowest } \\
\text { value }\end{array}$ & Average & Ranking \\
\hline Islamic Arab & 1.09 & 4.24 & 0.22 & 1.90 & 4.24 & 0.22 & $\mathbf{1 . 8 6}$ & 2 \\
\hline $\begin{array}{c}\text { Palestinian } \\
\text { Islamic }\end{array}$ & 1.04 & 3.26 & 2.36 & 0.72 & 3.26 & 0.72 & $\mathbf{1 . 8 5}$ & 3 \\
\hline $\begin{array}{c}\text { Palestinian } \\
\text { investment }\end{array}$ & 0.24 & 3.37 & 0.59 & 0.14 & 3.37 & 0.14 & $\mathbf{1 . 0 8}$ & 4 \\
\hline Palestine & 1.96 & 1.20 & 1.03 & 3.50 & 3.50 & 1.03 & $\mathbf{1 . 9 3}$ & 1 \\
\hline Al-Quds & 0.84 & 0.65 & 1.08 & 0.68 & 1.08 & 0.65 & $\mathbf{0 . 8 1}$ & 6 \\
\hline the National & 0.22 & 0.19 & 0.90 & 2.31 & 2.31 & 0.19 & $\mathbf{0 . 9 0}$ & 5 \\
\hline The average & 0.90 & 2.15 & 1.03 & 1.54 & & & $\mathbf{1 . 4 0}$ & \\
\hline
\end{tabular}

It is clear from the previous table, the variation in levels of appropriate timing between banks, and the following matters have been observed according to the previous descriptive statistics:

1. The highest value for the appropriate timing between banks was for the Arab Islamic Bank in 2015 .

2. The lowest value for the appropriate timing between banks was for the National Bank in 2015.

3. The Bank of Palestine has the highest average timing during the years, followed by the Arab Islamic Bank, followed by the Palestinian Islamic Bank, followed by the Palestinian Investment Bank, followed by the National Bank, while the Bank of Al- Quds ranked last. 
Table 5: The level of declared profits quality (unusual dues) for the banks listed on the Palestine Exchange

\begin{tabular}{|c|c|c|c|c|c|c|c|c|c|}
\hline The bank & $\mathbf{2 0 1 4}$ & $\mathbf{2 0 1 5}$ & $\mathbf{2 0 1 6}$ & $\mathbf{2 0 1 7}$ & $\begin{array}{c}\text { Highest } \\
\text { value }\end{array}$ & $\begin{array}{c}\text { lowest } \\
\text { value }\end{array}$ & Average & $\begin{array}{c}\text { Quality } \\
\text { level }\end{array}$ & Ranking \\
\hline Islamic Arab & 19.03 & 18.59 & 51.42 & 86.51 & 86.51 & 18.59 & $\mathbf{4 3 . 8 9}$ & High & 1 \\
\hline $\begin{array}{c}\text { Palestinian } \\
\text { Islamic }\end{array}$ & 35.22 & 63.94 & 38.15 & 36.64 & 63.94 & 35.22 & $\mathbf{4 3 . 4 9}$ & High & 2 \\
\hline $\begin{array}{c}\text { Palestinian } \\
\text { investment }\end{array}$ & -15.75 & 35.29 & -4.45 & -19.96 & 35.29 & -19.96 & $\mathbf{- 1 . 2 2}$ & Low & 4 \\
\hline Palestine & - & 78.36 & 158.89 & - & 158.89 & - & $\mathbf{- 6 0 . 7 9}$ & Low & 6 \\
\hline Al-Quds & -37.40 & - & 60.84 & -34.43 & 60.84 & -37.40 & $\mathbf{- 1 1 . 0 5}$ & Low & 5 \\
\hline the National & 4.02 & 5.03 & 7.01 & 8.86 & 8.86 & 4.02 & $\mathbf{6 . 2 3}$ & High & 3 \\
\hline The average & -30.45 & 28.00 & 51.98 & -35.83 & & & $\mathbf{3 . 4 2}$ & High & \\
\hline
\end{tabular}

It is clear from the previous table, the varied levels of the quality of profits announced between the banks, and the following things have been observed according to the previous descriptive statistics:

1. The highest value of the quality of profits announced between banks was for Bank of Palestine in 2016.

2. The lowest value of the quality of profits announced between banks was for Bank of Palestine in 2017 .

3. The Arab Islamic Bank achieved the highest average quality of profits announced during the years, followed by the Palestinian Islamic Bank, then the National Bank, then the Palestinian Investment Bank, then Al-Quds Bank, while Bank of Palestine ranked last.

4. The banks that announced the average quality of profits declared high quality are (the Arab Islamic Bank, the Palestinian Islamic Bank, and the National Bank), while the ones that received a low quality of profits are (the Palestinian Investment Bank, the Al-Quds Bank, and the Bank of Palestine).

\section{Second: Extraction of predictive (estimated) values for the coming years to 2032 (15 years)}

As we said earlier, it is to calculate the estimated value for future years, it is necessary to extract the average growth rate for each variable from each of the banks, and it was calculated by calculating the average growth rate for each year from one year to another, and then calculating the arithmetic average for it, and the results are shown In the following tables.

Table 6: Average growth rate of variable accuracy for banks listed on the Palestine Exchange

\begin{tabular}{|l|c|c|}
\hline The bank & $\begin{array}{c}\text { Average growth } \\
\text { rate }\end{array}$ & Ranking \\
\hline Islamic Arab & -0.047 & 3 \\
\hline $\begin{array}{l}\text { Palestinian } \\
\text { Islamic }\end{array}$ & -1.313 & 4 \\
\hline $\begin{array}{l}\text { Palestinian } \\
\text { investment }\end{array}$ & -2.107 & 6 \\
\hline Palestine & 1.206 & 1 \\
\hline Al-Quds & -1.792 & 5 \\
\hline the National & 0.362 & 2 \\
\hline The average & 1.133 & \\
\hline
\end{tabular}

It is noted through the previous table that the highest growth rate in the accuracy variable was for the Bank of Palestine and the lowest was for Al-Quds Bank, where the percentage was for the decline. 
Table 7: Average rate of variable growth appropriate for the banks listed on the Palestine Exchange

\begin{tabular}{|l|c|c|}
\hline \multicolumn{1}{|c|}{ The bank } & $\begin{array}{c}\text { Average growth } \\
\text { rate }\end{array}$ & Ranking \\
\hline Islamic Arab & -0.124 & 6 \\
\hline $\begin{array}{l}\text { Palestinian } \\
\text { Islamic }\end{array}$ & -0.031 & 4 \\
\hline $\begin{array}{l}\text { Palestinian } \\
\text { investment }\end{array}$ & 0.066 & 1 \\
\hline Palestine & 0.014 & 3 \\
\hline Al-Quds & -0.114 & 5 \\
\hline the National & 0.028 & 2 \\
\hline The average & $\mathbf{- 0 . 0 5 3}$ & \\
\hline
\end{tabular}

It is noted from the previous table that the highest growth rate in the fitness variable was for the Palestinian Investment Bank and the lowest was for the Arab Islamic Bank.

Table 8: Average rate of growth of the appropriate timing variable for banks listed on the Palestine Exchange

\begin{tabular}{|c|c|c|}
\hline The bank & rage growth rate & Ranking \\
\hline Islamic Arab & 3.193 & 2 \\
\hline Palestinian Islamic & 0.388 & 5 \\
\hline $\begin{array}{c}\text { Palestinian } \\
\text { investment }\end{array}$ & 3.818 & 1 \\
\hline Palestine & 0.623 & 4 \\
\hline Al-Quds & 0.022 & 6 \\
\hline the National & 1.722 & 3 \\
\hline The average & $\mathbf{0 . 4 5 4}$ & \\
\hline
\end{tabular}

It is noted from the previous table that the highest growth rate in the appropriate timing variable was for the Palestinian Investment Bank and the lowest was for Al-Quds Bank.

Table 9: Average growth rate of profit quality variable for banks listed on the Palestine Exchange

\begin{tabular}{|c|c|c|}
\hline The bank & rage growth rate & Ranking \\
\hline Islamic Arab & 0.816 & 1 \\
\hline Palestinian Islamic & 0.101 & 3 \\
\hline $\begin{array}{c}\text { Palestinian } \\
\text { investment }\end{array}$ & -0.136 & 4 \\
\hline Palestine & -1.119 & 5 \\
\hline Al-Quds & -2.389 & 6 \\
\hline the National & 0.219 & 2 \\
\hline The average & $\mathbf{- 0 . 6 1 1}$ & \\
\hline
\end{tabular}

It is noted from the previous table that the highest growth rate in the profit quality variable was for the Arab Islamic Bank and the lowest was for Al-Quds Bank.

After extracting the growth rates for the variables, the estimated (predictive) data for each variable is calculated for a period of (15) years to come, through the following formula:

$$
\mathrm{y}^{\wedge}=\mathrm{X}(\text { mean })(1+\mathrm{g}) \mathrm{t}
$$

The square root values of absolute values were taken and negative values were neglected after being calculated to modify the data to be appropriate to the model used, and the results were as follows: 
Table 10: The estimated values of the precision variable

\begin{tabular}{|l|c|c|c|c|c|c|}
\hline & $\begin{array}{c}\text { Islamic } \\
\text { Arab }\end{array}$ & $\begin{array}{c}\text { Palestinian } \\
\text { Islamic }\end{array}$ & $\begin{array}{c}\text { Palestinian } \\
\text { investment }\end{array}$ & Palestine & Al-Quds & $\begin{array}{c}\text { the } \\
\text { National }\end{array}$ \\
\hline $\mathbf{2 0 1 8}$ & 5.40 & 5.66 & 9.82 & 25.20 & 14.68 & 8.93 \\
\hline $\mathbf{2 0 1 9}$ & 5.53 & 8.60 & 17.30 & 37.43 & 24.53 & 10.42 \\
\hline $\mathbf{2 0 2 0}$ & 5.66 & 13.08 & 30.50 & 55.60 & 41.00 & 12.16 \\
\hline $\mathbf{2 0 2 1}$ & 5.79 & 19.90 & 53.76 & 82.58 & 68.50 & 14.19 \\
\hline $\mathbf{2 0 2 2}$ & 5.93 & 30.26 & 94.76 & 122.66 & 114.47 & 16.55 \\
\hline $\mathbf{2 0 2 3}$ & 6.07 & 46.01 & 167.02 & 182.19 & 191.27 & 19.32 \\
\hline $\mathbf{2 0 2 4}$ & 6.21 & 69.97 & 294.40 & 270.61 & 319.60 & 22.54 \\
\hline $\mathbf{2 0 2 5}$ & 6.36 & 106.41 & 518.92 & 401.94 & 534.04 & 26.31 \\
\hline $\mathbf{2 0 2 6}$ & 6.51 & 161.82 & 914.66 & 597.01 & 892.37 & 30.70 \\
\hline $\mathbf{2 0 2 7}$ & 6.66 & 246.08 & 1612.21 & 886.75 & 1491.11 & 35.82 \\
\hline $\mathbf{2 0 2 8}$ & 6.81 & 374.23 & 2841.72 & 1317.10 & 2491.60 & 41.80 \\
\hline $\mathbf{2 0 2 9}$ & 6.97 & 569.09 & 5008.88 & 1956.31 & 4163.37 & 48.78 \\
\hline $\mathbf{2 0 3 0}$ & 7.14 & 865.44 & 8828.78 & 2905.74 & 6956.85 & 56.92 \\
\hline $\mathbf{2 0 3 1}$ & 7.30 & 1316.09 & 15561.83 & 4315.95 & 11624.65 & 66.42 \\
\hline $\mathbf{2 0 3 2}$ & 7.48 & 2001.42 & 27429.68 & 6410.56 & 19424.39 & 77.51 \\
\hline
\end{tabular}

Table 11: Estimated values of the suitability variable

\begin{tabular}{|l|c|c|c|c|c|c|}
\hline & $\begin{array}{c}\text { Islamic } \\
\text { Arab }\end{array}$ & $\begin{array}{c}\text { Palestinian } \\
\text { Islamic }\end{array}$ & $\begin{array}{c}\text { Palestinian } \\
\text { investment }\end{array}$ & Palestine & $\begin{array}{c}\text { Al- } \\
\text { Quds }\end{array}$ & $\begin{array}{c}\text { the } \\
\text { National }\end{array}$ \\
\hline $\mathbf{2 0 1 8}$ & 1.10 & 1.14 & 1.19 & 1.07 & 1.18 & 1.17 \\
\hline $\mathbf{2 0 1 9}$ & 1.03 & 1.12 & 1.23 & 1.07 & 1.11 & 1.19 \\
\hline $\mathbf{2 0 2 0}$ & 0.96 & 1.10 & 1.26 & 1.08 & 1.04 & 1.20 \\
\hline $\mathbf{2 0 2 1}$ & 0.90 & 1.08 & 1.31 & 1.09 & 0.98 & 1.22 \\
\hline $\mathbf{2 0 2 2}$ & 084 & 107 & 135 & 110 & 092 & 124 \\
\hline $\mathbf{2 0 2 3}$ & 0.79 & 1.05 & 1.39 & 1.10 & 0.87 & 1.25 \\
\hline $\mathbf{2 0 2 4}$ & 0.74 & 1.03 & 1.44 & 1.11 & 0.82 & 1.27 \\
\hline $\mathbf{2 0 2 5}$ & 0.69 & 1.02 & 1.49 & 1.12 & 0.77 & 1.29 \\
\hline $\mathbf{2 0 2 6}$ & 0.65 & 1.00 & 1.53 & 1.13 & 0.72 & 1.31 \\
\hline $\mathbf{2 0 2 7}$ & 0.61 & 0.98 & 1.58 & 1.14 & 0.68 & 1.33 \\
\hline $\mathbf{2 0 2 8}$ & 0.57 & 0.97 & 1.64 & 1.14 & 0.64 & 1.34 \\
\hline $\mathbf{2 0 2 9}$ & 0.53 & 0.95 & 1.69 & 1.15 & 0.60 & 1.36 \\
\hline $\mathbf{2 0 3 0}$ & 0.50 & 0.94 & 1.74 & 1.16 & 0.57 & 1.38 \\
\hline $\mathbf{2 0 3 1}$ & 0.46 & 0.92 & 1.80 & 1.17 & 0.53 & 1.40 \\
\hline $\mathbf{2 0 3 2}$ & 0.43 & 0.91 & 1.86 & 1.18 & 0.50 & 1.42 \\
\hline
\end{tabular}

Table 12: The estimated values of the appropriate timing variable

\begin{tabular}{|c|c|c|c|c|c|c|}
\hline & Islamic Arab & $\begin{array}{c}\text { Palestinian } \\
\text { Islamic }\end{array}$ & $\begin{array}{c}\text { Palestinian } \\
\text { investment }\end{array}$ & Palestine & $\begin{array}{c}\text { Al- } \\
\text { Quds }\end{array}$ & $\begin{array}{c}\text { the } \\
\text { National }\end{array}$ \\
\hline $\mathbf{2 0 1 8}$ & 2.79 & 1.60 & 2.28 & 1.77 & 0.91 & 1.57 \\
\hline $\mathbf{2 0 1 9}$ & 5.72 & 1.89 & 5.01 & 2.25 & 0.92 & 2.58 \\
\hline $\mathbf{2 0 2 0}$ & 11.71 & 2.22 & 10.99 & 2.87 & 0.93 & 4.26 \\
\hline $\mathbf{2 0 2 1}$ & 23.97 & 2.62 & 24.12 & 3.66 & 0.94 & 7.03 \\
\hline $\mathbf{2 0 2 2}$ & 49.09 & 3.09 & 52.95 & 4.66 & 0.95 & 11.60 \\
\hline $\mathbf{2 0 2 3}$ & 100.52 & 3.64 & 116.23 & 5.94 & 0.96 & 19.14 \\
\hline $\mathbf{2 0 2 4}$ & 205.82 & 4.28 & 255.12 & 7.56 & 0.97 & 31.58 \\
\hline $\mathbf{2 0 2 5}$ & 421.44 & 5.05 & 559.99 & 9.64 & 0.98 & 52.11 \\
\hline $\mathbf{2 0 2 6}$ & 862.95 & 5.95 & 1229.18 & 12.28 & 0.99 & 85.98 \\
\hline $\mathbf{2 0 2 7}$ & 1767.00 & 7.00 & 2698.05 & 15.64 & 1.00 & 141.86 \\
\hline $\mathbf{2 0 2 8}$ & 3618.12 & 8.25 & 5922.21 & 19.92 & 1.01 & 234.07 \\
\hline $\mathbf{2 0 2 9}$ & 7408.52 & 9.72 & 12999.24 & 25.38 & 1.02 & 386.20 \\
\hline $\mathbf{2 0 3 0}$ & 15169.78 & 11.45 & 28533.28 & 32.33 & 1.03 & 637.22 \\
\hline $\mathbf{2 0 3 1}$ & 31061.84 & 13.49 & 62630.45 & 41.19 & 1.05 & 1051.39 \\
\hline $\mathbf{2 0 3 2}$ & 63602.63 & 15.89 & 137473.62 & 52.47 & 1.06 & 1734.76 \\
\hline
\end{tabular}


Table 13: The estimated values of the declared profit quality variable

\begin{tabular}{|l|c|c|c|c|c|c|}
\hline & Islamic Arab & $\begin{array}{c}\text { Palestinian } \\
\text { Islamic }\end{array}$ & $\begin{array}{c}\text { Palestinian } \\
\text { investment }\end{array}$ & Palestine & Al-Quds & $\begin{array}{c}\text { the } \\
\text { National }\end{array}$ \\
\hline $\mathbf{2 0 1 8}$ & 8.93 & 6.92 & 1.18 & 11.35 & 6.12 & 2.76 \\
\hline $\mathbf{2 0 1 9}$ & 12.03 & 7.26 & 1.26 & 16.52 & 11.26 & 3.04 \\
\hline $\mathbf{2 0 2 0}$ & 16.21 & 7.62 & 1.34 & 24.05 & 20.74 & 3.36 \\
\hline $\mathbf{2 0 2 1}$ & 21.85 & 7.99 & 1.43 & 35.01 & 38.17 & 3.71 \\
\hline $\mathbf{2 0 2 2}$ & 29.45 & 8.38 & 1.52 & 50.96 & 70.27 & 4.10 \\
\hline $\mathbf{2 0 2 3}$ & 39.69 & 8.79 & 1.62 & 74.18 & 129.35 & 4.52 \\
\hline $\mathbf{2 0 2 4}$ & 53.48 & 9.23 & 1.73 & 107.98 & 238.12 & 4.99 \\
\hline $\mathbf{2 0 2 5}$ & 72.07 & 9.68 & 1.84 & 157.18 & 438.34 & 5.51 \\
\hline $\mathbf{2 0 2 6}$ & 97.13 & 10.16 & 1.96 & 228.80 & 806.90 & 6.09 \\
\hline $\mathbf{2 0 2 7}$ & 130.90 & 10.66 & 2.09 & 333.06 & 1485.38 & 6.72 \\
\hline $\mathbf{2 0 2 8}$ & 176.40 & 11.18 & 2.23 & 484.82 & 2734.34 & 7.42 \\
\hline $\mathbf{2 0 2 9}$ & 237.73 & 11.73 & 2.38 & 705.74 & 5033.48 & 8.20 \\
\hline $\mathbf{2 0 3 0}$ & 320.37 & 12.31 & 2.53 & 1027.32 & 9265.83 & 9.05 \\
\hline $\mathbf{2 0 3 1}$ & 431.75 & 12.91 & 2.70 & 1495.43 & 17056.89 & 9.99 \\
\hline $\mathbf{2 0 3 2}$ & 581.84 & 13.54 & 2.88 & 2176.84 & 31398.98 & 11.03 \\
\hline
\end{tabular}

Data validity test for statistical analysis:

The study model belongs to the General Linear Model GLM, which before applying it requires many conditions, and because it was relied on the method of regular least squares, there are many conditions that must be met and the most important of them are:

\section{Moderate probability distribution of residues (Normality Test)}

It is used to check how close the data is to its normal distribution, and a test (Kolmogorov- Smirnov, Shapiro-Wilk) has been used, and the decision rule is to accept the null hypothesis that the data follow the normal distribution, if the probability level is greater than 0.05 .

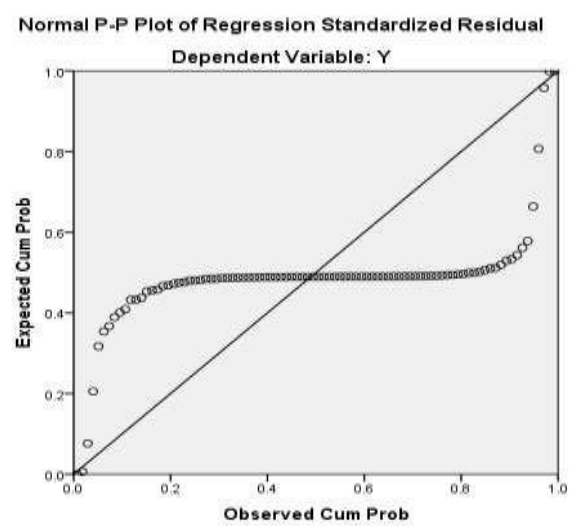

Figure (1): normal distribution test (independent variable: accuracy, function: quality of profits)

The previous figure shows that the residues are distributed regularly, not randomly, and differently from the line, which means that the residues are distributed non- moderately (that is, the data do not follow the normal distribution), and this is confirmed by the Colomogrove-Samranov test and Shapiro-Willik test, where the probability value reached 0,000 It is less than 0.05 , and therefore the null hypothesis is rejected and the alternative hypothesis is accepted which states that the data do not follow the normal distribution. 


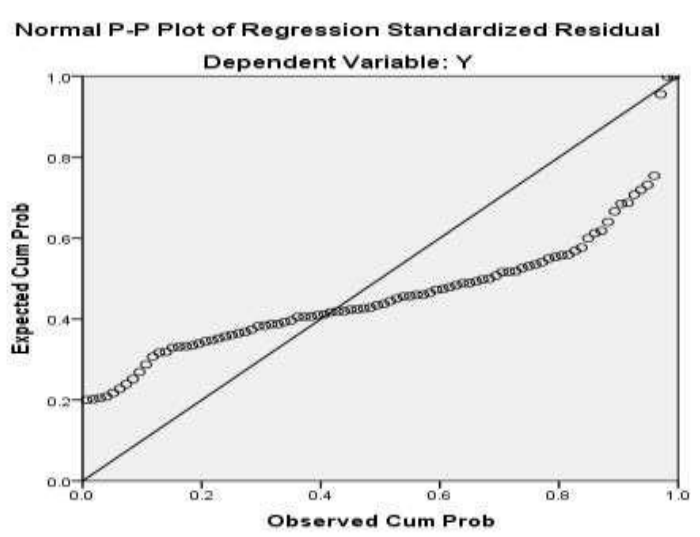

Figure (2): normal distribution test (independent variable: convenience, dependent: quality of profits)

The previous figure shows that the residues are distributed regularly, not randomly, and differently from the line, which means that the residues are distributed non-moderately (that is, the data do not follow the normal distribution), and this is confirmed by the Colomogrove- Samranov test and Shapiro-Willik test, where the probability value reached 0,000 It is less than 0.05 , and therefore the null hypothesis is rejected and the alternative hypothesis is accepted which states that the data do not follow the normal distribution.

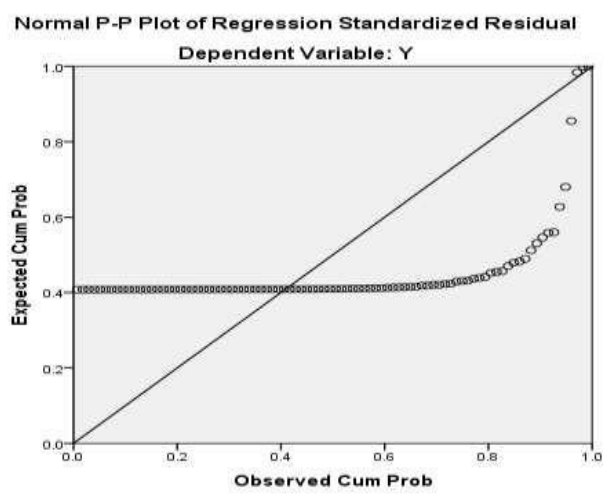

Figure (3): Natural Distribution Test (independent variable: good timing, dependent: quality of profits)

The previous figure shows that the residues are distributed regularly, not randomly, and differently from the line, which means that the residues are distributed non-moderately (that is, the data do not follow the normal distribution), and this is confirmed by the Colomogrove- Samranov test and Shapiro-Willik test, where the probability value reached 0,000 It is less than 0.05, and therefore the null hypothesis is rejected and the alternative hypothesis is accepted which states that the data do not follow the normal distribution.

Table 14: Normal Distribution Test (Kolmogorov-Smirnov, Shapiro-Wilk)

\begin{tabular}{|c|c|c|c|c|c|c|c|}
\hline \multirow{2}{*}{ S.N } & variable & \multicolumn{2}{|c|}{ Kolmogorov-Smirnov } & \multicolumn{3}{|c|}{ Shapiro-Wilk } \\
\cline { 3 - 8 } & & Statistic & Df & Sig. & Statistic & Df & Sig. \\
\hline 1 & $\begin{array}{c}\text { Standardized Residual } \\
\text { (Independent- Accuracy) }\end{array}$ & 0.379 & 90 & 0.000 & 0.409 & 90 & 0.000 \\
\hline 2 & $\begin{array}{c}\text { Standardized Residual } \\
\text { (Independent- Fit) }\end{array}$ & 0.267 & 90 & 0.000 & 0.453 & 90 & 0.000 \\
\hline 3 & $\begin{array}{c}\text { Standardized Residual } \\
\text { (Independent- Timing) }\end{array}$ & 0.407 & 90 & 0.000 & 0.240 & 90 & 0.000 \\
\hline
\end{tabular}

To overcome this problem, the natural log (natural log). Of these variables has been taken, and since the sample size is large (greater than 30), the problem of not naturally distributing data will not affect the validity of the research model.

\section{2- Autocorrelation Test:}

The problem of self-correlation appears in the model if the adjacent observations are interconnected, which will affect the validity of the model, as the effect of the independent variables will be influenced on the dependent variable largely due to that correlation. To verify this, a Durbin Watson D-W test was used. 
Table 15: Self-link test (D-W)

\begin{tabular}{|c|c|}
\hline Sample & Durbin Watson \\
\hline Independent variable: precision & 0.935 \\
\hline
\end{tabular}

Looking at the du value from the Durbin Watson Critical Table of Values at $\mathrm{k}$ is equal to one true (because there is only one independent variable), in front of the degree of error freedom (88) and is extracted from (the Table of variance analysis), and at the level of significance 0.05 , equal (1.679), since the self-correlation condition is as follows ( 2 DW $<4-\mathrm{du}$ ), and therefore we find that the value of DW for the two models does not fall within the range of (D-statistic), and at the same time falls within half of the condition, and in this case the decision is not specified In the sense that we cannot determine whether there is a self- correlation or not because ( $\mathrm{dl}<\mathrm{DW}<\mathrm{du}$ ), and as a precaution to overcome the problem a first degree of slowdown (Lag1) was taken when testing the search model.

Table 16: Self-Test (D-W)

\begin{tabular}{|c|c|}
\hline Sample & Durbin Watson \\
\hline Independent variable: precision & 0.951 \\
\hline
\end{tabular}

Looking at the du value from the Durbin Watson Critical Table of Values at $\mathrm{k}$ is equal to one true (because there is only one independent variable), in front of the degree of error freedom (88) and is extracted from (the Table of variance analysis), and at the level of significance 0.05 , equal (1.679), since the self-correlation condition is as follows ( $2<\mathrm{DW}$ $<4-\mathrm{du}$ ), and therefore we find that the value of DW for the two models does not fall within the range of (D-statistic), and at the same time falls within half of the condition, and in this case the decision is not specified In the sense that we cannot determine whether there is a self- correlation or not because ( $\mathrm{dl}<\mathrm{DW}<\mathrm{du}$ ), and as a precaution to overcome the problem a first degree of slowdown (Lag1) was taken when testing the search model.

Table 17: Self-link test (D-W)

\begin{tabular}{|c|c|}
\hline Sample & Durbin Watson \\
\hline Independent variable: convenience & 0.962 \\
\hline
\end{tabular}

Looking at the du value from the Durbin Watson Critical Table of Values at $\mathrm{k}$ is equal to one true (because there is only one independent variable), in front of the degree of error freedom (88) and is extracted from (the Table of variance analysis), and at the level of significance 0.05, equal (1.679), since the self-correlation condition is as follows ( $2<\mathrm{DW}<4-\mathrm{du}$ ), and therefore we find that the value of DW for the two models does not fall within the range of (Dstatistic), and at the same time fall within half of the condition, and in this case the decision is not specified In the sense that we cannot determine whether there is a self- correlation or not because ( $\mathrm{dl}<\mathrm{DW}<\mathrm{du}$ ), and as a precaution to overcome the problem a first degree of slowdown (Lag1) was taken when testing the search model.

\section{3- Homoscedasticity Test:}

One of the important assumptions of the classical regression models, and the application of the regular least squares method (OLS) is that the random error variance is constant (Homoscedasticity) in addition to that the average must be equal to zero.

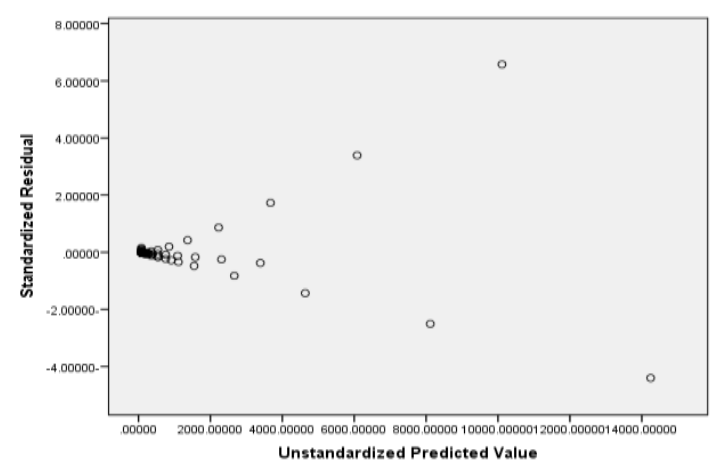

Figure 4: Stability test for random error variance (independent variable - accuracy)

Figure 4 shows that we can monitor a specific and linear pattern of residues, as the residues do not take a random shape, as the distribution and distribution of the residues does not take a random shape on both sides of the line that represents zero, which means that there is a problem of heterogeneity or stability in the contrast of errors, Which means accepting the nihilistic hypothesis that this model suffers from the instability of the random error variance, and this problem was overcome by using the (White) method, since if the random error variance is not fixed, some statistical methods 
are used to overcome this problem, such as testing ( White), which is routinely made using the software package after being discovered by the software itself.

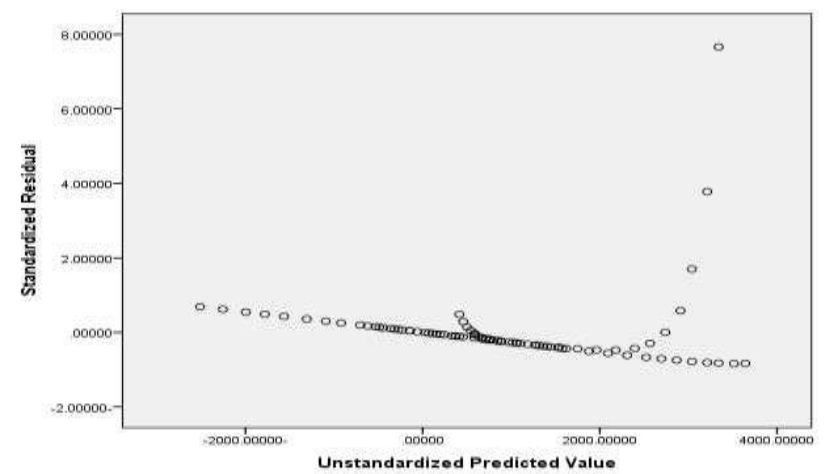

Figure 5: Stability test for random error variance (independent variable - suitability)

Figure (5) shows that we can monitor a specific and linear pattern of residues, as the residues do not take a random shape, as the spread and distribution of the residues does not take a random shape on both sides of the line that represents zero, which means that there is a problem of heterogeneity or stability in the contrast of errors, Which means accepting the nihilistic hypothesis that this model suffers from the instability of the random error variance, and this problem was overcome by using the (White) method, since if the random error variance is not fixed, some statistical methods are used to overcome this problem, such as a test (White), which is routinely made using the software package after being discovered by the software itself.

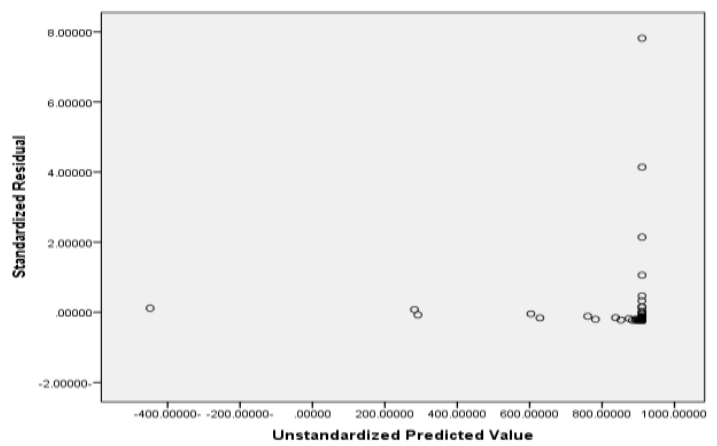

Figure (6): Stability test for random error variance (independent variable - appropriate timing)

Figure (6) shows that we cannot monitor a specific and linear pattern of the remainder, since the remaining ones take a random shape, as the spread and distribution of the remaining takes a random shape on both sides of the line that represents zero, which means that there is no problem of heterogeneity or stability in the variance of errors, which The rejection of the nihilistic hypothesis means that this model suffers from the inconsistency of the random error variance.

\section{4- Linear interference test:}

The strength of the linear model depends on the assumption of the independence of each of the independent variables, and if this condition is not met, then the general linear model is not suitable for application, and cannot be considered good for the estimation process, and Collinearity Diagnostics was used by calculating the Tolerance parameter for each variable Of the independent variables, and then find a parameter (Variance Inflation Factor VIF), as this test is a measure of the effect of correlation between the independent variables, and in the event of a value (VIF) greater than 5 this indicates the presence of the problem of Multicollinearity of the independent variable concerned, Table 18 shows the results of the test. This test was used in the multiple regression model, which includes independent variables (accuracy, relevance, and appropriate timing). This model requires non-linear duplication between explanatory (independent) variables.

Table 18: Linear interference test (VIF)

\begin{tabular}{|c|c|c|c|}
\hline S.N. & Variable & Tolerance & VIF \\
\hline 1 & Precision & 0.530 & 1.886 \\
\hline 2 & Convenience & 0.947 & 1.056 \\
\hline 3 & Good timing & 0.519 & 1.926 \\
\hline
\end{tabular}

It is noted from the previous table that the value of (VIF) for all independent variables is below (5), which means that the study model is free from the linear interference problem. 


\section{Study hypotheses test:}

The first main hypothesis: There is a statistically significant effect at the level of $(\alpha \leq 0.05)$ of the quality of financial reporting in developing the level of quality of profits announced in the financial reports of banks listed on the Palestine Stock Exchange, and two sub-hypotheses are subdivided from them:

1. There is a statistically significant effect at the level of significance $(\alpha \leq 0.05)$ of the accuracy of financial reporting in developing the level of quality of profits announced in the financial reports of banks listed on the Palestine Exchange.

Table (18) shows that the value of the determination coefficient equals 0.304 , and this means that the accuracy variable explains $30.4 \%$ of the change in the quality of profits, or that $30.4 \%$ of the changes that occur in the quality of profits are attributed to accuracy and the rest $69.6 \%$ due to other factors not included in it. The model includes a random error, as the probability value corresponding to the regression variance analysis is 0,000 , which is less than 0.05 , and the slope value of the regression line is 0.517 , which indicates a positive effect at the level of significance $(\alpha \leq 0.05)$ of accuracy on the level of declared profit quality. For banks listed on the Palestine Exchange, meaning that accuracy directly affects the quality of profits announced in the financial reports of banks listed on the Palestine Exchange.

The researcher attributes this to the fact that the banks listed on the Palestine Stock Exchange are concerned with the level of accuracy of the information provided and ways of communicating it to investors, which reflected positively on the groups that benefit from this information so that they can evaluate the investment opportunities available to them and know the risks inherent in investing their money and maximizing their wealth, and these results agreed with some Studies such as Al-Shujairy and Al-Mazury (2008).

\section{Estimated regression model:}

Profit quality $=78.069+517$. Accuracy for financial reporting

Table 19: Regression model results

\begin{tabular}{|c|c|c|c|}
\hline \multicolumn{4}{|c|}{ Model parameters and statistics } \\
\hline Fixed amount & 78.069 & $\begin{array}{c}\text { Correlation coefficient } \\
\qquad R\end{array}$ & 0.559 \\
\hline Gradient slope & 0.517 & $\begin{array}{l}\text { Adjusted coefficient of } \\
\quad \text { determination } R^{2}\end{array}$ & 0.304 \\
\hline Probability value (Sig) & 0.000 & Value of $\mathrm{F}$ & 39.949 \\
\hline
\end{tabular}

*Model estimated statistically significant at the level of significance $(\alpha \leq 0.0 .5)$

2. There is a statistically significant effect at the level of significance $(\alpha \leq 0.0 .5)$ of the appropriateness of financial reporting in developing the level of quality of profits announced in the financial reports of banks listed on the Palestine Stock Exchange.

Table 20 shows that the value of the determination coefficient equals 0.110 , and this means that the fitness variable explains $11 \%$ of the change in the quality of profits, or that $11 \%$ of the changes that occur in the quality of the profits are attributable to the fitness and the rest $89 \%$ is due to other factors not included in it. The model includes random error, as the probability value corresponding to the regression variance analysis is 0.001 , which is less than 0.05 , and the slope value of the regression line equals 4304.710, which indicates an adverse effect at the significance level $(\alpha \leq 0.0 .5)$ to suit the declared profit quality level. It is reported by the banks listed on the Palestine Stock Exchange, meaning that the relevance adversely affects the quality of the profits announced in the financial reports of the banks listed on the Palestine Exchange.

The researcher attributes this to the fact that the banks listed on the Palestine Stock Exchange did not care to provide the appropriate information to the investors, which negatively affected the groups benefiting from this information, as the convenience represents a major feature in the field of financial reporting quality, which means the ability of the information provided to influence the decision through change events In the decision, as a result of providing the information, it differed with the study of Al-Shujairy and Al-Mazury (2008).

\section{Estimated regression model:}

Profit quality $=5493.147-4304.710$. Convenient for financial reporting 
Table 20: Regression model results

\begin{tabular}{|c|c|c|c|}
\hline \multicolumn{4}{|c|}{ Model parameters and statistics } \\
\hline Fixed amount & 5493.147 & $\begin{array}{c}\text { Correlation coefficient } \\
R\end{array}$ & 0.346 \\
\hline Gradient slope & -4304.710 & $\begin{array}{c}\text { Adjusted coefficient of } \\
\text { determination } R^{2}\end{array}$ & 0.110 \\
\hline Probability value (Sig) & 0.001 & Value of $\mathrm{F}$ & 11.963 \\
\hline
\end{tabular}

*Model estimated statistically significant at the level of significance $(\alpha \leq 0.0 .5)$

3. There is a statistically significant effect at the level of significance $(\alpha<=0.05)$ of the appropriate timing of financial reporting in developing the level of quality of profits announced in the financial reports of banks listed on the Palestine Exchange.

Table 21 shows that the probability value corresponding to the regression variance analysis is 0.675 , which is greater than 0.05 , and the slope value of the regression line is -0.010 , which indicates the presence of a reverse effect, but this effect is statistically significant at the significance level $(\alpha<=0.05)$, Meaning that the appropriate timing does not affect the quality of the profits announced in the financial reports of the banks listed on the Palestine Exchange.

The researcher attributes this to the fact that the banks listed on the Palestine Stock Exchange did not care about the appropriate timing of the information provided and the means of communicating it to the investors, which negatively affected the groups that benefit from this information, as providing the information at the appropriate time is one of the requirements of the quality of financial reporting, and it differed with the study of Al-Shujairi and Al-Mazury (2008)

Estimated regression model:

Profit quality $=910.358-0.010$. Timeliness of financial reporting

Table 21: Regression model results

\begin{tabular}{|c|c|c|c|}
\hline \multicolumn{4}{|c|}{ Model parameters and statistics } \\
\hline Fixed amount & 910.358 & Correlation coefficient \\
& & $R$ & 0.045 \\
\hline Gradient slope & -0.010 & $\begin{array}{c}\text { Adjusted coefficient of } \\
\text { determination } R^{2}\end{array}$ & 0.002 \\
\hline Probability value (Sig) & 0.675 & Value of F & 0.177 \\
\hline
\end{tabular}

*Model estimated statistically significant at the level of significance $(\alpha \leq 0.0 .5)$

\section{Multiple Linear Regression Analysis:}

Results of the multiple linear regression analysis tests: (The effect of the quality of financial reporting on the quality of profits announced in the financial reports of banks listed on the Palestine Exchange)

To test the effect between the dimensions of financial reporting quality (independent variables) and the quality of declared profits (dependent variable), multiple linear regression analysis was used, and Table 22 shows the test results:

Table 22: Multiple Linear Regression Analysis - dependent variable (declared profit quality)

\begin{tabular}{|c|c|c|c|c|c|c|}
\hline $\begin{array}{l}\text { Independent } \\
\text { variables }\end{array}$ & $\begin{array}{c}\text { Regression } \\
\text { coefficients } \\
\text { ((B) }\end{array}$ & $\begin{array}{l}\text { Std. } \\
\text { Error }\end{array}$ & $\begin{array}{l}\text { Standard } \\
\text { beta }\end{array}$ & $\begin{array}{l}T \text { test } \\
\text { value }\end{array}$ & $\begin{array}{l}\text { Probability } \\
\text { value Sig. }\end{array}$ & $\begin{array}{l}\text { Sig./Not } \\
\text { Sig. }\end{array}$ \\
\hline Fixed amount & 5044.799 & 690.280 & & 7.308 & 0.000 & Sig. \\
\hline Precision & 1.041 & .062 & 1.127 & 16.753 & 0.000 & Sig. \\
\hline Convenience & $-4735.416-$ & 626.109 & $-.381-$ & $-7.563-$ & 0.000 & Sig. \\
\hline Good timing & $-.161-$ & .015 & $-.730-$ & $-10.738-$ & 0.000 & Sig. \\
\hline \multicolumn{3}{|c|}{ Correlation coefficient $=0.891$} & \multicolumn{3}{|c|}{$\begin{array}{l}\text { Modified selection coefficient }= \\
0.787\end{array}$} & \\
\hline \multicolumn{3}{|c|}{ Test value $\mathrm{F}=110.368$} & \multicolumn{3}{|c|}{ Probability value $=0.000$} & \\
\hline
\end{tabular}

From Table 22, it is clear that:

- It was found that the adjusted coefficient of determination is equal to 0.787 , which means that the independent variables (accuracy, suitability, and appropriate timing) explain $78.7 \%$ of the changes that occur in the dependent variable (quality of profits), and the remainder $21.3 \%$ is due to other factors not included in the model, including random error . 
- It was found that the value of the probability value P. Value corresponding to the analysis of variance is 0.000 which is less than the significance level 0.05 , therefore the regression model is significant and there is at least one regression coefficient different from zero.

- The probability value P. Value of the regression coefficients was found to be 0,000 and is less than the 0.05 level of significance for all variables, including the constant, which means that the beta coefficients of the estimated regression model are significant. The positive influencing variables are (accuracy).

- The opposite influencing variables are (appropriate, appropriate timing).

- The resulting regression line equation can be written as: Dependent variable $=$ constant $+\mathrm{b} 1 . \mathrm{X} 1+\mathrm{b} 2 . \mathrm{X} 2+\mathrm{E}$.

Profit quality $=5044.799+1.041$. Accuracy -4735.416 . Appropriateness -161 . Timing $+\mathrm{E}$.

\section{Conclusions}

After completing the theoretical and practical aspects, the following results were reached:

- There is a positive impact at the level of significance $(\alpha<=0.05)$ of accuracy on the level of the quality of profits declared for the banks listed on the Palestine Stock Exchange, meaning that accuracy directly affects the quality of profits announced in the financial reports of banks listed on the Palestine Exchange.

- There is an adverse effect at the level of significance $(\alpha<=0.05)$ of the compatibility on the level of the quality of profits declared for the banks listed on the Palestine Exchange, meaning that the relevance adversely affects the quality of profits announced in the financial reports of the banks listed on the Palestine Exchange.

- There is an adverse effect at the level of significance $(\alpha<=0.05)$ of the appropriate timing on the level of the quality of profits declared for the banks listed on the Palestine Stock Exchange, meaning that the appropriate timing does not affect the quality of profits announced in the financial reports of the banks listed on the Palestine Exchange.

- There is an important role for the quality of financial reporting in developing the level of quality of profits announced in the financial reports of banks listed on the Palestine Stock Exchange.

- The highest value of interbank balance was for Al Quds Bank in 2014.

- The lowest value for interbank balance was in the Palestinian Investment Bank in 2015 and 2016.

- Al-Quds Bank received the highest average score during the years, followed by the Arab Islamic Bank, then the National Bank, then the Palestinian Islamic Bank, then the Palestinian Investment Bank, while Bank of Palestine ranked last.

- The highest value for the appropriate timing between banks was for the Arab Islamic Bank in 2015.

- The lowest value for the appropriate timing between banks was for the National Bank in 2015.

- The Bank of Palestine has the highest average timing during the years, followed by the Arab Islamic Bank, followed by the Palestinian Islamic Bank, followed by the Palestinian Investment Bank, followed by the National Bank, while the Bank of Al- Quds ranked last.

- The highest value of the quality of profits announced between banks was for Bank of Palestine in 2016.

- The lowest value for the quality of profits announced between banks was for Bank of Palestine in 2017.

- The Arab Islamic Bank achieved the highest average quality of profits announced during the years, followed by the Palestinian Islamic Bank, then the National Bank, then the Palestinian Investment Bank, then Al-Quds Bank, while Bank of Palestine ranked last.

- The banks that have an average quality of profits advertised at a high quality are (Arab Islamic Bank, Palestinian Islamic Bank, and the National Bank), and those th a thave a low quality of profits are (Palestinian Investment Bank, Al Quds Bank, and Bank of Palestine).

- The highest growth rate in the accuracy variable was for the Bank of Palestine, and the lowest was for Al-Quds Bank, where the percentage was for the decline.

- The highest growth rate in the appropriateness variable was for the Palestinian Investment Bank, and the lowest was for the Arab Islamic Bank.

- The highest growth rate in the appropriate timing variable was for the Palestinian Investment Bank, and the lowest was for Al-Quds Bank.

- The highest growth in the quality of profits variable was for the Arab Islamic Bank, and the lowest was for Al-Quds Bank.

\section{Recommendations}

In light of the researcher's findings, a set of recommendations can be presented as follows:

- The need for the information provided by the banks listed on the Palestine Exchange through financial reporting to be beneficial to their users, so they must be accurate, appropriate and timely.

- The need for banks listed on the Palestine Exchange to provide the appropriate information to investors to influence their decisions, negatively or positively.

- The need for banks listed on the Palestine Exchange to provide information to their users in a timely manner; otherwise this information will lose its value.

- The necessity of continuously developing financial reporting reports in light of the emerging and changing needs of users of financial reports and other stakeholders.

- The need for great attention to financial reporting, as interest in it enhances the confidence of users of financial reports, while unifying its foundations in a manner that does not lead to inconsistencies in information. 
- Finally, the researcher recommends that other research work to explore more methods used in developing the quality of the declared profits, and future studies should work on setting clear and specific standards and controls for the quality of profits to include finding uniform and comparable standards.

\section{References:}

[1]. Ibrahim, Farid Muharram Farid (2014): "The Relationship between Quality of Profits and the Company's Exposure to the Risks of Financial Failure", Ain Shams University, Faculty of Commerce, Journal of Accounting Thought, First Issue, Egypt.

[2]. Al-Jajjawi, Talal and Al-Masoudi, Haider (2014): "Intermediate Financial Accounting", Darar Al-Kutub Mozazoon - Publishers, 2nd Edition, Karbala, Iraq.

[3]. 3. Hamdan, Allam Muhammad Musa (2012): "The role of audit committees in the continuity of profits as evidence of their occurrence," Journal of the Islamic University for Economic and Administrative Studies, Volume Twenty, First Issue, Gaza, Palestine.

[4]. Reda, Sameh Mohamed (2012): "The effect of audit quality on the quality of profits, and their impact on cash distributions in Egyptian industrial joint-stock companies," Jordanian Journal of Business Administration, Volume 8, No. 4.

[5]. Al-Shujairy, Muhammad Hosh and Al-Mazuri, Abbas Hassan (2008): "The Impact of Quality of Financial Reporting on the Value of the Facility," a research paper on an unpublished Master Thesis, University of Duhok, Iraq.

[6]. Saleh, Ammar Abdul Qadir (2010): "The role of investors in assessing the quality of financial reporting and its implications for investment decision-making - a field study in

[7]. the Iraq Stock Exchange," an unpublished Master Thesis, College of Administration and Economics, University of Baghdad, Iraq.

[8]. Obaid, Fida and Akbar, Yunus (2016): “The Quality of Profits and Their Impact on Financial Statements", Journal of Baghdad College for Economic Sciences University, 48th count.

[9]. Azwail, Hisham and Bardai, Barjubai (2018): "The Role of Implementing Corporate Governance in Quality of Profits" from the viewpoint of the directors of financial departments in industrial companies operating in the Ramallah Governorate, Journal of Economy and Finance, Volume 4, Count 1.

[10]. Al-Faouri, Rifaat Abdel-Halim (2011): “Accounting Reserve and Quality of Profit Measurement,” Arab Journal of Management, Second Issue, Cairo, Egypt.

[11]. Al-Masoudi, Haider Ali Jarad and Al-Jabouri, Ali Khalaf Kati (2016): "The Effect of Quality of Financial Reporting on Enhancing the Value of Economic Unit", Karbala University, College of Management and Economics, Southern Technical University, Journal of Technology, Nasiriyah, Iraq.

[12]. Al-Muaini, Saad and Nuri, Waad (2017): "The Impact of Quality of Financial Reporting on Added Market Value" An applied study in a sample of commercial banks listed on the Iraq Stock Exchange, Technical Magazine, Volume Thirty, No. 4.

[13]. Melegy, Magdy Melegy (2013): “The Impact of Internal Auditing Activities on the Management and Quality of Profits as an Approach to Improving Relevance and Reliability on Financial Statements", Tanta University, Faculty of Commerce, Scientific Journal, Volume 1, Number 4, Egypt

[14]. Altamuro, J., \& Beatty, A. (2006). Do internal control reforms improve earnings quality. W paper, The Ohio State University.

[15]. Beest, F. V., Braam, G. J. M., \& Boelens, S. (2009). Quality of Financial Reporting: measuring qualitative characteristics.

[16]. Beuselinck, C., \& Manigart, S. (2007). Financial reporting quality in private equity backed companies: The impact of ownership concentration. Small Business Economics, 29(3), 261-274.

[17]. Dechow, P. M., \& Dichev, I. D. (2002). The quality of accruals and earnings: The role of accrual estimation errors. The accounting review, 77(s-1), 35-59.

[18]. Dechow, P. M., \& Schrand, C. M. (2004). Earnings quality.

[19]. De-jun, W. U. (2009). What are affecting earnings quality: A summarization. Journal of Modern Accounting and Auditing, 5(5), 53.

[20]. Demerjian, P. R., Lev, B., Lewis, M. F., \& McVay, S. E. (2013). Managerial ability and earnings quality. The accounting review, 88(2), 463-498.

[21]. Machuga, S., \& Teitel, K. (2007). The effects of the Mexican corporate governance code on quality of earnings and its components. Journal of International Accounting Research, 6(1), 37.

[22]. Nashwa, G. (2003). Audit Committees: The solution to quality financial reporting?. The CPA Journal, $73(12), 6$.

[23]. Penman, S. H., \& Zhang, X. J. (2002). Accounting conservatism, the quality of earnings, and stock returns. The accounting review, 77(2), 237-264. 